\title{
Does a Financial Expert's Audit Committee Presence Enhance American Nonprofit Financial Reporting Quality? Donors Decide
}

\author{
R. Steven Flynn \\ Department of Accountancy, Thomas More College, Crestview Hills, Kentucky, USA \\ *Corresponding Author: flynns@thomasmore.edu
}

Copyright (C) 2013 Horizon Research Publishing All rights reserved.

\begin{abstract}
California's passage of the Nonprofit Integrity Act in 2004, followed by the enactment of similar legislation in other American states, has resulted in a series of new financial reporting requirements for many larger nonprofit organizations. Chief among the provisions of several of these legislative pieces is the requirement for nonprofit entities to form separate audit committees. Following the lead established in the for-profit sector, advocates have strongly urged nonprofit organizations to include at least one financial expert among audit committee members to augment actual and perceived financial reporting integrity. However, advocates' acknowledgement of the challenge of recruiting these individuals leads one to question their ultimate worth to nonprofit organizations. Recognizing the significance of this issue, this study investigates individual donors' impressions regarding the inclusion of financial experts among nonprofit audit committee members. Using an experimental case as the basis for exploration, the study finds that donors generally do not perceive financial experts as enhancing the credibility of nonprofit organizations' financial statements. In light of the significance of individual donor contributions to entities' continued financial sustainability, these findings represent potentially important considerations for nonprofit organizations as they weigh the costs and benefits of enlisting busy financial professionals for audit committee service.
\end{abstract}

Keywords Nonprofit Audit Committees, Financial Experts, Nonprofit Reporting Quality, Donor Impression

\section{Introduction and Background}

A new era of financial reporting for publicly traded companies began when the United States Congress passed the Sarbanes-Oxley Act (SOX) a decade ago. Although SOX exempts nonprofit organizations from all but two of its provisions (mandated written whistle-blowing and document retention policies), advocates began to call for entities' voluntary adoption of many of the legislation's requirements shortly after its passage (Neely, 2011; Grant Thornton, 2010; Board Source and Independent Sector, 2006). California legislators heeded these calls in 2004 when they passed the Nonprofit Integrity Act. Following California's lead, many other states have enacted similar legislation (Neely, 2011; Grant Thornton, 2010; Board Source and Independent Sector, 2006).

Chief among the provisions of the Nonprofit Integrity Act and its legislative siblings is the requirement for larger nonprofit organizations to create a separate audit committee (Neely, 2011; Grant Thornton, 2010; Board Source and Independent Sector, 2006). Audit committees, typically comprised of three to five members of the governing board, are charged with the oversight of the external audit, including the hiring of the auditor and the resolution of financial reporting disputes between the auditor and management (Arens et al., 2012). Experts view audit committees as a means to visibly enhance the integrity of the financial reporting process. Advocates have maintained that nonprofit audit committees, like their for-profit counterparts, should include at least one committee member with financial expertise, although current legislation does not mandate such a requirement (Grant Thornton, 2010; Board Source and Independent Sector, 2006). Advocates argue that a financial expert's presence on an audit committee would further strengthen both the actual and perceived credibility of a nonprofit entity's financial statements (Grant Thornton, 2010; Board Source and Independent Sector, 2006).

While nonprofit organizations may have some difficulty in forming an audit committee, they would, as advocates have readily acknowledged, likely encounter a greater number of obstacles in enlisting a financial expert for committee membership (Grant Thornton, 2010; Board Source and Independent Sector, 2006). Prior to the formal adoption of the SOX expertise requirement, publicly traded firms openly expressed this fear (Raghunandan and Rama, 2007; Carcello et al., 2006; SEC, 2002).As a result, the Securities and 
Exchange Commission, charged with implementing the SOX requirement, broadened its definition of a financial expert to include those with indirect accounting and/or finance experience (e.g., a CEO with a management background but experienced in performing financial statement analyses) (Raghunandan and Rama, 2007; Carcello et al., 2006; SEC, 2002). Not surprisingly, recent studies have found that CEOs, not CPAs, comprise the majority of formally designated audit committee financial experts for publicly traded firms (Anonymous, 2007; Raghunandan and Rama, 2007; Carcello et al., 2006; Williams, 2005).

The difficulty that nonprofit organizations would likely face in recruiting financial experts for audit committee service leads one to question their potential value to the nonprofit financial reporting process. While they may greatly aid an organization in its oversight responsibilities of the audit process, financial experts' ability to augment the perceived integrity of nonprofit organizations' financial reporting remains less clear. This latter issue forms the central basis of the current investigation. Using actual donors in an experimental setting, the study addresses the following research question: Do individual donors believe that the inclusion of a financial expert on a nonprofit entity's audit committee enhances the reliability of the organization's financial statements? This examination is important for two primary reasons. First, gifts from individual donors currently comprise the greatest source of financial contributions received yearly by nonprofit organizations in the United States (AAFRC, 2012). Thus, the significance of the beliefs of donors to nonprofit entities' continued financial sustainability is apparent. Second, prior research has established the relevance of accounting information to individual donors when determining their contribution amounts (GuideStar, 2011; Keating et al., 2008; Parsons, 2003; Tinkelman, 1999; Greenlee and Brown, 1999; Weisbrod and Dominguez, 1986).If the credibility of this information influences donors' giving decisions, then the ultimate value of a financial expert to a nonprofit entity may rest on his/her ability to enhance donors' impressions of reporting integrity.

Several sections comprise the remaining portions of this paper. The next section develops the study's hypothesis. It is followed by discussions of the research methodology employed and the statistical analysis used in evaluating the study's findings. The paper concludes with a delineation of the study's limitations and implications.

\section{Development of Hypothesis}

Prior empirical studies in the for-profit field have generally supported the notion that nonprofessional investors value audit committees' financial experts with direct accounting or finance knowledge; they typically perceive such individuals as augmenting the credibility of a firm's financial statements. Flynn (2009) found, for example, that nonprofessional investors felt that audit committee members with direct financial expertise (i.e., those with accounting backgrounds) enhanced the reliability of the financial reporting process; investors did not, however, ascribe a comparable level of support to experts with only indirect financial knowledge (i.e., a CEO with a general management background and financial statement analysis experience). In a later study, Flynn (2010) also documented an increase in perceived earnings quality as the number of formally designated financial experts grew.

The above studies suggest that individual donors may view the naming of a financial expert to a nonprofit audit committee as an enhancement to the quality of the entity's financial statements. Advocates for the inclusion of financial expertise implicitly argue this point (Grant Thornton, 2010; Board Source and Independent Sector, 2006). Based on these assertions, the following directional hypothesis is proposed: H1: Individual donors perceive a financial expert's presence on a nonprofit organization'saudit committee as enhancing the credibility of the entity's financial statements.

\section{Research Methodology}

The study recruited 52 individual donors to test the above hypothesis in an experimental setting. All participants were active donors, with the majority having contributed $\$ 100$ or more to nonprofit organizations during the prior year. Most reported giving on an annual, as opposed to a weekly or monthly, basis. Organizations to which subjects had made monetary contributions included: human service organizations; religious organizations; youth development organizations; health and disease research organizations; educational institutions; arts organizations; recreational organizations; and environmental organizations. Nearly all donors were employed full-time and had, on average, over 12 years of full-time work experience. Their mean age was 34.At the time of the experiment, all participants were enrolled in an evening MBA management accounting course at a private institution.

A for-profit case previously developed by $\mathrm{Ng}$ and $\mathrm{Tan}$ (2003) served as the basis for the experiment's materials. Using the case's principle features, (Ng and Tan, 2003), the present study's scenario centered on a private university undergoing a financial statement audit for the primary purpose of the re-accreditation of its academic programs. In the course of their investigation, auditors proposed a reclassification of a currently reported unrestricted $\$ 500,000$ gift received during the past year. Auditors believed that generally accepted accounting principles (GAAP) and the donor's expressed wishes directly supported reclassifying the entire gift as restricted. If followed, the proposed adjustment would produce a negative balance in the university's unrestricted net assets account, a result that that the institution feared would endanger its reaccreditation status. (Accrediting agencies often place special importance on educational institutions' financial viability. See Southern Association of Colleges and Schools (SACS) (2012), for 
example.) To solve the reporting dispute, the university turned to its audit committee. This committee, comprised of three non-employee members of the university's board of trustees, was entirely independent of management.

Case materials manipulated the audit committee's degree of financial expertise at three different levels, corresponding to three different experimental groups to which donors were randomly assigned: the formal designation of one committee member as a financial expert (18 participants); an explicit acknowledgment of the absence of financial expertise among committee members (18 participants); and no mention of the presence or absence of financial expertise among committee members (16 participants). After reading case materials, subjects indicated the probability (from 0 percent to 100 percent) that the audit committee would agree with the auditors' proposed reclassification.

\section{Analysis of Results}

Table 1 presents participants' predicted probability estimates of the audit committee's acceptance of the audit adjustment. Since GAAP and the donor's wishes appeared to support the reclassification, a higher (lower) probability implicitly reflected a belief in greater (lesser) financial reporting credibility. Surprisingly, as seen in Table 1, subjects felt that the lowest level of reporting quality would occur when a financial expert was named (45.13\%).In contrast, participants assigned their highest probability estimate when the case made no mention of audit committee financial expertise $(50.44 \%)$.

Table 1. Participants' Mean Probability Estimates (Standard Deviations)

\begin{tabular}{|c|c|}
\hline Financial Expertise Condition & $\begin{array}{l}\text { Mean Probability } \\
\text { Estimate }\end{array}$ \\
\hline One Designated Expert & $\begin{array}{c}45.13 \% \\
(34.87 \%)\end{array}$ \\
\hline $\begin{array}{c}\text { Acknowledgment of the Absence of a } \\
\text { Designated Expert }\end{array}$ & $\begin{array}{c}50.28 \% \\
(30.26 \%) \\
\end{array}$ \\
\hline No Mention of Financial Expertise & $\begin{array}{c}50.44 \% \\
(30.80 \%)\end{array}$ \\
\hline
\end{tabular}

In light of the relatively high standard deviations, however, the three estimates did not appear to differ appreciably. To formally test for the financial expert effect, an ANOVA, with the degree of financial expertise as the independent variable and the probability estimate as the dependent variable, was run. The lack of a statistically significant effect revealed in Table $2(p=0.856)$ indicates that donors did not believe that the financial expert's presence would affect the audit committee's acceptance of the auditor's proposed reclassification. Thus, participants did not perceive an enhancement to the institution's financial reporting process as a result of the committee's inclusion of a financial expert. This finding fails to support the study's directional hypothesis and casts some doubt on the ability of a financial expert's service to significantly influence donors' beliefs concerning financial reporting integrity.
Table 2. ANOVA Test of Financial Expertise Effect

\begin{tabular}{|c|c|c|c|}
\hline Source & $\begin{array}{c}\text { Mean Square } \\
\text { Error }\end{array}$ & $\begin{array}{c}\mathrm{F} \\
\text { Statistic }\end{array}$ & p-value \\
\hline $\begin{array}{c}\text { Degree of Financial } \\
\text { Expertise }\end{array}$ & 160.669 & 0.156 & 0.856 \\
\hline Error & 1030.111 & & \\
\hline
\end{tabular}

\section{Limitations, Discussion, and Conclusion}

As an empirical study, the current investigation suffers from several limitations, including the absence of the random selection of subjects, the summarized nature of the case materials, and participants' potentially high level of accounting knowledge. In addition, the small number of subjects employed in the study may have restricted the power of the statistical test to detect a significant difference among the three experimental groups, a concern that could potentially alter the primary implications of the investigation. Despite these shortcomings, the study's findings suggest that, from the perspective of the individual donor, nonprofit organizations may gain little in terms of enhanced financial reporting quality from the naming of a financial expert to their audit committees. These results stand in contrast to empirical findings in the for-profit sector that have generally reported a significant association between perceived reporting reliability and: the professional background of the designated expert (Flynn, 2009); and the number of named committee members with financial expertise (Flynn, 2010).These studies have not, though, explicitly addressed the financial expert's presence or absence, which may account, in part, for their different results. Also, as noted above, the small sample size of the present investigation and its resultant effect on the power of its statistical test may have played a role in the study's findings. It is important to recognize that financial experts may contribute greatly to a nonprofit audit committee's actual operations. They may substantially enhance its ability to deal with complicated financial matters and may provide a high degree of oversight of the auditor's work. Clearly, nonprofit organizations may benefit in many ways from a financial expert's presence. However, if perceptions regarding financial reporting credibility ultimately influence donors' giving decisions, then nonprofit organizations may expect to reap few monetary rewards from their efforts to recruit busy financial experts for audit committee service, an important consideration in today's competitive marketplace for individual donor funds.

\section{REFERENCES}

[1] American Association of Fundraising Counsel (AAFRC), Giving USA 2012: The Annual Report on Philanthropy for 
the Year 2011, AAFRC, Indianapolis, Indiana, 2012.

[2] Anonymous, "Most Audit Committees Still Lack Accountants," Journal of Accountancy, Vol. 203 (3), 2007, 14.

[3] Arens, A.A., Elder, R. J., and Beasley, M. S., Auditing and Assurance Services: An Integrated Approach, 14th edition (2012), Pearson Prentice Hall, Upper Saddle River, New Jersey, 2012.

[4] BoardSource and Independent Sector, "The Sarbanes-Oxley Act and Implications for Nonprofit Organizations," 2006, Available at http://boardsource.org and http://independentsector.org.

[5] Carcello, J. V., Hollingsworth, C. W., and Neal, T. L., “Audit Committee Financial Experts: A Closer Examination Using Firm Designations,"Accounting Horizons, Vol. 20 (4), 2006. $351-373$

[6] Flynn, R. S., "Multiple Financial Experts, Audit Firm Tenure and the Nonprofessional Investor," Journal of Academy of Business and Economics, Vol.10 (1), 2010, 131 - 138.

[7] Flynn, R. S., "The Effects of Financial Experts' Professional Background and Nonaudit Fee Disclosures on Earnings Quality Assurance: An Empirical Investigation," International Journal of Business Research, Vol. 9 (4), 2009, $67-77$.

[8] Grant Thornton, Not-for-Profit Audit Committee Handbook, 2010, Available at http://www.GrantThornton.com/nfp.

[9] Greenlee, J. S., and Brown, K. L., "The Impact of Accounting Information on Contributions to Charitable Organizations," Research in Accounting Regulation, Vol. 13, 1999, 111 125.

[10] GuideStar, "Money for Good II Shows How a Small Shift Can Give Nonprofits a Big Gift this Giving Season," 2011, Available at http: //www.GuideStar.org.

[11] Keating, E. K., Parsons, L. M., and Roberts, A. A., "Misreporting Fundraising: How Do Nonprofit Organizations Account for Telemarketing Campaigns?", The Accounting Review, Vol. 83 (2), 2008, 417 - 446.
[12] Neely, D. G., "The Impact of Regulations on the U.S. Nonprofit Sector: Initial Evidence from the Nonprofit Integrity Act of 2004," Accounting Horizons, Vol. 25 (1), $2011,107-125$.

[13] Ng, T. B., and Tan, H., "Effects of Authoritative Guidance Availability and Audit Committee Effectiveness on Auditors' Judgments in an Auditor-Client Negotiation Context," The Accounting Review, Vol. 78 (3), 2003, 801 - 818.

[14] Parsons, L., "Is Accounting Information from Nonprofit Organizations Useful to Donors? A Review of Charitable Giving and Value Relevance," Journal of Accounting Literature, Vol. 22, 2003, 104-129.

[15] Raghunandan, K., and Rama, D. V., "Determinants of Audit Committee Diligence," Accounting Horizons, Vol. 21 (3), 2007, $265-279$.

[16] Securities and Exchange Commission (SEC), Proposed Rule: Disclosure Required by Sections 404, 406 and 407 of the Sarbanes-Oxley Act of 2002, Government Printing Office, Washington, D. C., 2002.

[17] Southern Association of Colleges and Schools (SACS), "Commission on Colleges. Accrediting Standards," 2012, Available at http://www.sacscoc.org/pdf/2012PrinciplesOfAcreditation.p df.

[18] Tinkelman, D., "Factors Affecting the Relation Between Donations to Not-For-Profit Organizations and an Efficiency Ratio," Research in Government and Nonprofit Accounting, Vol. 10, 1999, 135-161.

[19] Weisbrod, B. A., and Dominguez, N. D., "Demand for Collective Goods in Private Nonprofit Markets: Can Fundraising Expenditures Help Overcome Free Rider Behavior?", Journal of Public Economics,Vol. 30 (1), 1986, 83-96.

[20] Williams, S. P., "Meet the Experts," Accounting Horizons, Vol. 19 (4), 2005, $255-265$. 